\title{
Land use land cover change detection in the mining areas of V. D. Yalevsky coal mine- Russia
}

\author{
Al-shateri Hoshmand Ahmed Azeez ${ }^{1 *}$, Shuchrat Mukhitdinov ${ }^{2}$ \\ ${ }^{1}$ Natioanl University of Science and Technology MISIS, Москва, 117997, Россия \\ ${ }^{2}$ Tashkent State Technical University, Tashkent, Uzbekistan
}

\begin{abstract}
The dynamics of land use/land cover (LULC) changes, the effect of coal mining on the LULC changes, and the regional environmental impact are discussed in this study. The different land use classes mainly Forest, Water Bodies, Road, Mining Area, Agriculture and Grass in the study area of V. D. Yalevsky coal field area in Prokorvisk city in Kamerovo region of Russia are identified. On the other hand the impact of V. D. Yalevsky coal mine activities on LULC change on the environment and teritory are discussed. The LULC changes in the V. D. Yalevsky coal field area were analyzed for a period of 27 years e.g., from the year 1992 to 2019. The changes were detected on a 13-years time interval using Landsat-4 TM, Landsat-8 OLI. Furthermore supervised classification techniques using maximum likelihood method through ENVI (Environment for Visualizing Images) 5.1 software was utilized. In addition post classification change detection method through ENVI was used to investigate the changes. The study reveals decrecment in LULC cotogories of forest to $25.35 \mathrm{~km}^{2}$, water bodies to $-0.94 \mathrm{~km}^{2}$, agriculture to $-98.48 \mathrm{~km}^{2}$, road to $-10.80 \mathrm{~km}^{2}$. However increment in the rate of mining area to $100.72 \mathrm{~km}^{2}$ and grass cover $34.86 \mathrm{~km}^{2}$ during the study period. Meanwhile 90.18\% overall accuracy and (0.87) kappa coefitient for 1992 classified image, 93.41\% overall accuracy and (0.91) Kappa koefitient for 2006 classified image and $88.69 \%$ overall accuracy and (0.85) kappa coefitient for 2019 classified image were obtained.
\end{abstract}

Keywords: Land use/ Land cover, Change detection, V. D. Yalevsky coal mine area, Remote sensing.

\section{Introduction}

Change detection is the process of identifying differences in the state of an object or phenomenon by observing it at different times [1]. The earth's surface changes are divided into two categories i.e. land use and land cover (LULC). The term land use stands for the purpose for which the specific piece of land is used for e.g. agriculture, urbanization, mining, etc. The term land cover stands for the features which are present on the earth's surface for e.g. buildings, pavement, trees etc.

\footnotetext{
*Corresponding author: hoshmendg@gmail.com
} 
The need for monitoring and quantifying changes by remote sensing techniques and satellite imagery has been well recognized. From environmental point of view, the dynamic process of LULC change is an indispensable concern all over the world, which indicates global environmental change [2] and this has been recount as the most remarkable regional anthropogenic disruption of environment [3]. There is no doubt that the coal mining expansion benefits the local GDP significantly, but also causes environmental degradation and destroy original ecosystem balance due to the destruction of original land cover types [4]. Mining area caused a great deal of changes in landscape structure and enormous environmental disturbances, among them open-pit coal mine is one of the greatest landscape altering activities, and it's difficult to restore surface coal mine to the original ecological landscape [5].

Russia sits upon huge banks of some key mineral deposits. Kuznestk basin which is located in Russia, one of the largest coal fields in the world. In this frame work V.D. Yalevsky which is located in the city of Prokoryevsk at Kemerovo region, consider as the biggest and huge coal mine volume. As a developing country, the energy requirement in Russia is increasing day by day and the coal mining industries are eventually increasing their production to meet the requirement. In general, the natural resources occur in ecologically sensitive and endangered forest cover areas. In this context, it is essential to scrutinize the effect of mining on land use land cover change to minimize its impact on environment as well as for proper land management and decision making [6,7,8]. To ascertain such changes, earth resource satellite data are critically important and useful for land use/land cover change studies [9]. Today Remote snesing technology has enabled ecologists and natural resources managers to acquire timely data and observe periodical changes [10]. Acquiring timely Remote sensing data and application of GIS technology are very useful to observe and analyze the periodical changes of land forms and land cover [11]. Usually, the most standard method used for land use land cover change detection is post classification comparison method, which entails the comparison of independently produced classified images [1]. The V.D. Yalevsky coal mine in Prokoryevsk district at Kemerovo region in Russia has seen the coal mining activity for some time now. The LULC dynamics in the area is essential to monitor the influence of these activities, therfore in the present study, the dynamics of LULC changes, the effect of coal mining on LULC changes, and the regional environmental impact are discussed. Furthermore supervised classification technique maximum likelihood (ML) has been employed, by using Landsat satellite data, for period from 1992, to 2019. Landsat satellite imagery widely used in the study, because Landsat program is an archive of Earth images, easily accessible via the internet for free, large scale cover area, multi-temporal images (long time serious) and multi-spectral scanner are its benefits. The main objective of the paper is to understand the areal distribution of LULC in three difference times in the area (1992-2006 and 2019) and indicating changes during the mining exploration process, also indicating impact of coal mining on the dynamics of LULC changes.

\section{Study area}

The study area is V.D. Yalevsky, which is one of the largest valumes coal mining in Russia. V.D. Yalevsky located in a city of Prokoryevsk district at Kemerovo region, central Russia, on Aba River. A small village of 18th-century origin, it expanded rapidly in the 1920s to become the largest coal mining centre of the Kuznetsk Basin, although it is gradually declining. The total number of population of the city is about 216,700. It stands at the 88th position among largest populated cities of Russia. The total geographical area of the city is around $3.730 \mathrm{~km}^{2}$, in that about $616 \mathrm{~km}^{2}$ coverd to the present study. 
The location of the study area lies between $\left(54^{\circ} 11^{\prime} 29.60^{\prime \prime} \mathrm{N}\right)$ lattitude and $\left(87^{\circ}\right.$ 9'28.77"E) longitude, and elevation $278 \mathrm{~m} / 912.1$ feet. The total economy of the region is highly dependent on coal mining. Extraction of coking coal from the coal enriching plant is the main industry of the region. Prokopievsk has a continental climate. Winters are frosty and long, summers are cool and short. The warmest month in July, the average temperature +18.3 degrees Celsius. The coldest in January, the average temperature -15.9 degrees Celsius. The average annual rainfall $620 \mathrm{~mm}$. The location and map of the study area is shown in Fig1.

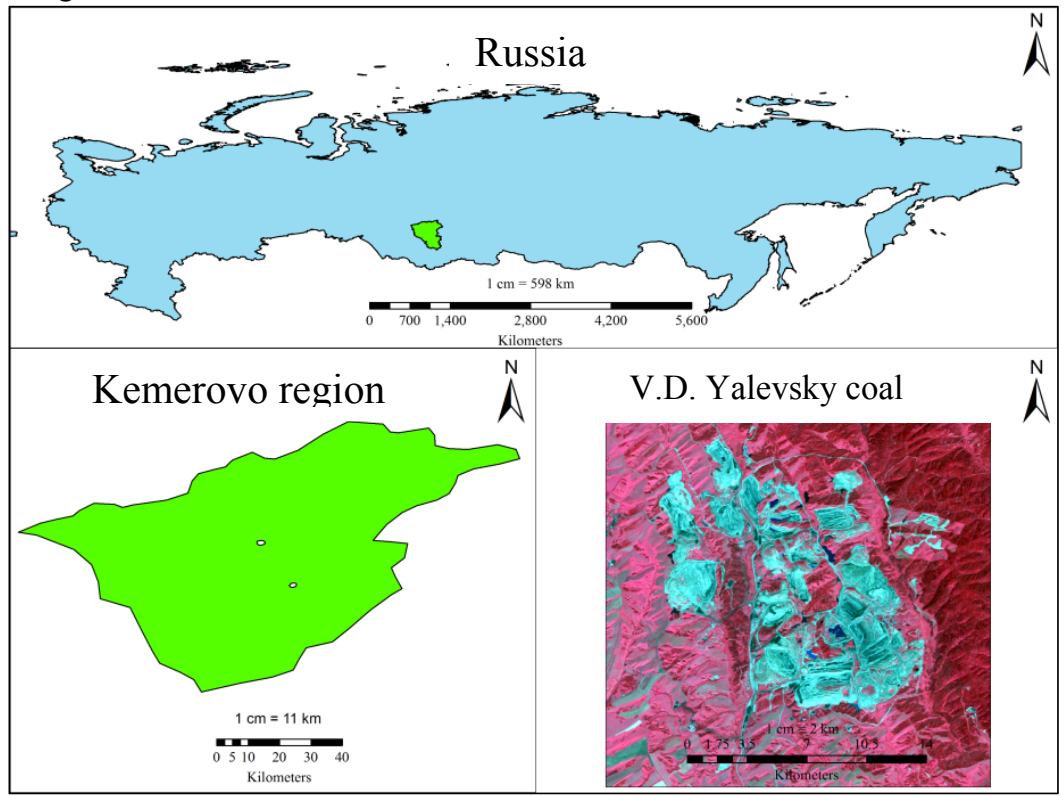

Fig. 1. Location map of the V.D. Yalevsky coal mine area

\section{Material and methods}

Spatial methods utilizing Landsat Satellite imagery in monitoring change was employed. The multi-dated Landsat data sets of V.D. Yalevsky coal mining area, a number of digital image processing techniques were adopted and land use/land cover maps for 3-year time i.e., for the years 1992, 2006 and 2019 were prepared. On the other hand Supervised classification techniques Maximum Likelihood Classification (MLC) algorithm was used to define each class and categorizing DN values in different classes in the study area. Post classification comparison method was used to measure the amount of healthy and declining each class categories in the area.

\subsection{Data acquisition}

The satellite data used for land use/land cover classification are derived from Landsat-4 Thematic Mapper for two-years time period of 1992 and 2006, whereas Landsat-8, OLI data is used for the year 2019. The Landsat- 4 and 8 sensors have a spectral resolution of 30 $\mathrm{m}$ and a swath of $185 \mathrm{~km}$ [11]. In addition satallite data of Sentinel-2A and Google Earth imagery in same time are used as ground truth to assessing accuracy assessment. These satellite data sets were obtained from [12]. All the data were projected to the same reference system UTM (zone 45) North and WGS 84 datum. The study area falls under the path 146 and row 022 in Worldwide Reference System of Landsat. The ground truth data 
were ascertained with the help of Google Erath and Sentinel-2A imagery. These data were used for classification and assessing accuracy assessment of the classified images. Employing multi-dated TM Landsat data sets of V.K. Yelevsky coal mining area, various digital image processing techniques were adopted to investiagte land use/landcover changes and prepare LULC maps of the study area for 3-year time 1992, 2006 and 2019.

\subsection{Mapping and accuracy assesmment}

First, all the three data sets went through image pre-processing and enhancement. The images atmosphericaly, radiometrically and geometrically coorected by using ENVI (Environment for Visualizing Images) software 5.1. Layer stacking operations were used to combine the different bands. All bands of image were used for the layer stacking in Landsat-4 TM visible to shortwave infrared (bands 1 to 5 and 7) and (1 to 7) in Landsat-8, OLI with pixel size $30 \mathrm{~m}$. A shapefile of the study area was then overlaid on each image as the area of interest (AOI) and a subset obtained.

On the other hand LULC maps for the years 1992, 2006 and 2019 produced after editing and finalization. The rate of the classes in $\mathrm{Km}^{2}$ was extracted, the percentage change for each year mesured against each LULC type and the rates divided acording to each individual year. A change in the area was indicated as either positive or negative, maximum and minimum as well. Six major LULC classes were implemented by Supervised classification tchniques, using ML algorithm with the help of ENVI 5.1 software. Postclassified images were cleaned for obtaining better accuracy results and for reduction of misclassification [13]. While classifying the images, mixed pixels cause a common problem because of the medium spatial resolution of the Landsat data sets (13).

Accuracy assessment has been carried out by employing the 'confusion matrix' [14] and 'Kappa' analysis [15] and images were evaluated. Gound truth data and ROI's method by using Sentinel-2A and Google Earth imagery were used for accuracy assessment in ENVI 9.1 software.

\subsection{Change detection}

For detecting and analyzing the change on earth's surface, various techniques are employed. post classification method is proved to be the most popular approach in change detection analysis. It requires the comparison of independently produced classified image. The approach of this method is based on the rectification of the classified images independently then the thematic maps are generated which is followed by the comparison of corresponding labels to identify the areas where change has occurred (Shivangi Mishra1., et al, 2017). In this case LULC change detection study for V.D. Yelekvsky coal mining area in Prokopivsk district in Kemerovo region was carried out by using post classification method. The images were downloaded from the Landsat-4(TM) and Landsat8 OLI image using ENVI 5.1 software. In addition to obtain the dynamic changes of each class catogories during the study period i.e., from 1992 to 2009, post classification comparison method and change detection statistics through ENVI 5.1software were used, to compute the trend, class total, net change, class change, percent change and rate of each LULC change between the years 1992 and ,2006 and 2019.

\section{Results and discussion}

Six major LULC classes categories -forest, water bodies, road, mining area, agriculture and grass land were recorded in the study area. The LULC maps of the study area for three 
different time periods are presented in Fig. 2. Spatial distribution, area statistics of six LULC categories and their percentages of the area covered by each LULC category for each years are also shown in Table1. Table 2 depicts the magnitude of change in different land use land cover categories in 3-year time span from 1992 to 2006 and 2006 to2019, net change and rate of change for each individual year illustrated as well. Table 3 show the statistics of change detection analysis for the study period 1992-2019 for each class catogories.

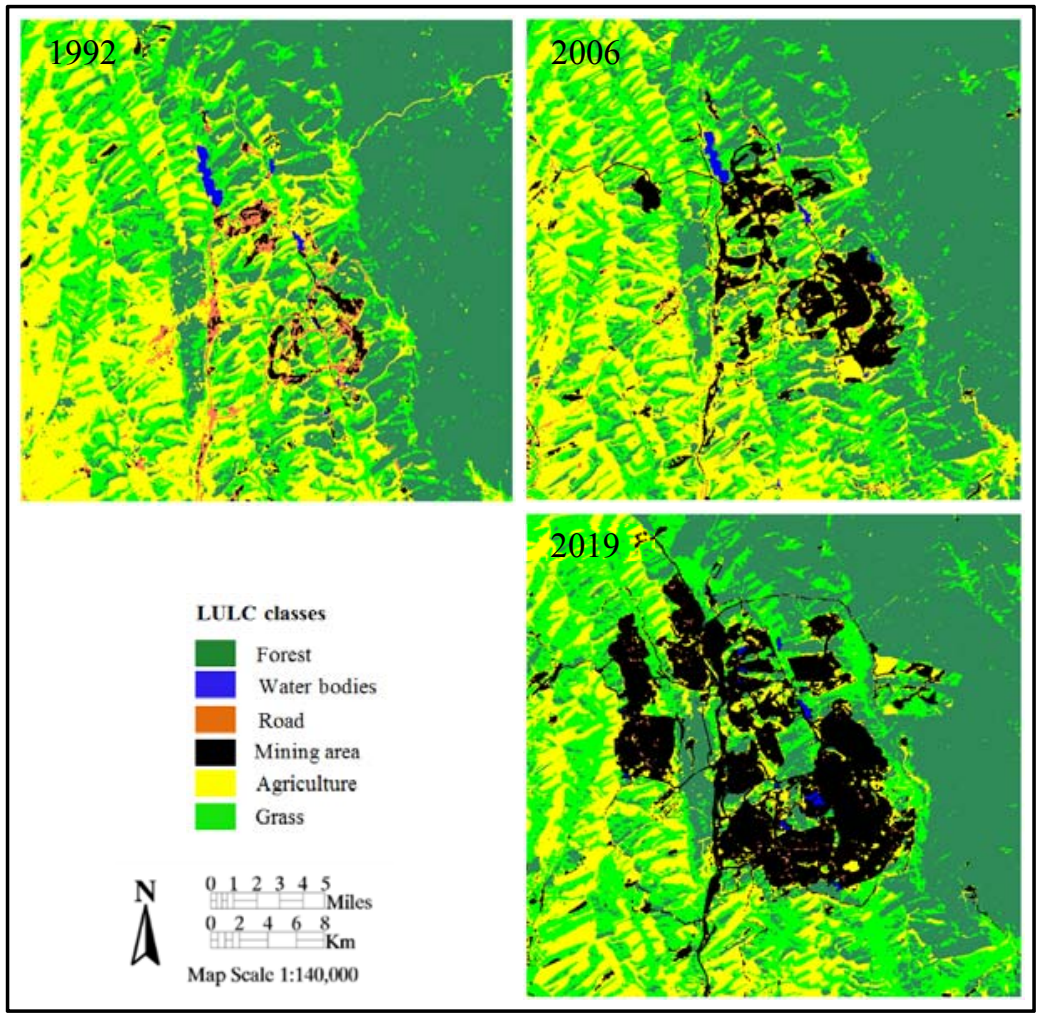

Fig. 2. Land use Map of 1992, 2006 and2019.

\subsection{Areal extent and change of LULC}

The results on various landform cover extents and their changes are presented in Fig2, and Tables $1-3$. The high altitude areas according to the study area are mainly covered by forest and low lying areas covered by water bodies. Coal mines area as a main part of the study is distributed mostly seen along the forest, grass, water and agriculture land.

The forest areal extent comprise the most biggest catogory in the study area, and shows increasing trend from 1992-2006. Forest cover land contain $241.01 \mathrm{~km}^{2}(39.16 \%)$ in the year 1992, and increased to $245.40 \mathrm{~km}^{2}$ (39.87) in the year 2006, however decreased to $215.66 \mathrm{~km}^{2}$ (35.04) in the year 2019 .

Water bodies contain the less part of the study area and shows decreasing gradually. The rate of the water bodes area is $2.12 \mathrm{~km}^{2}(0.34 \%)$ in the year $1992,1.94 \mathrm{~km}^{2}(0.32 \%)$ in the year 2006, and $1.18 \mathrm{~km}^{2}(0.19 \%)$ in the year 2019 .

The rate of Road class is the second smallest part of the area. The results shows conversion during the years. Th rate of roads $12.26 \mathrm{~km}^{2}(1.99 \%)$ in the year $1992,4.67 \mathrm{~km}^{2}$ 
$(0.76 \%)$ in the years 2006 and $1.46 \mathrm{~km}^{2}(0.24 \%)$ in the year2019. However It is observed that the land cover category of grass gradually extended from $142.60 \mathrm{~km}^{2}$

$(23.17 \%)$ in the year 1992 to $151.60 \mathrm{~km}^{2}(24.63 \%)$ in the year 2006 again and again to $177.46 \mathrm{~km}^{2}(28.83 \%)$ in the year 2019 .

The coal mining area that had spread over $10.68 \mathrm{~km}^{2}$ in $1992(1.74 \%)$, increased to $43.89 \mathrm{~km}^{2}(7.13 \%)$ in 2006 , again and again it increased to $111.40 \mathrm{~km}^{2}(18.10 \%)$ in the year 2019. The mining area comprises the opencast (open-pit) coal mines and overburden dumps. As a consequence, the area of mining and overburden dumps show constant increase in their aerial extents during the study period.

The Agriculture cover area comprises the second largest class of the study area and forms an important land cover class. The study reveals that agricultural land shrunken from $206.83 \mathrm{~km}^{2}(33.60 \%)$ in the year 1992 to $168.01 \mathrm{~km}^{2}(27.30 \%)$ in the year 2006 , and further decreased to $108.35 \mathrm{~km}^{2}(17.60 \%)$ in the year 2019 . Several reasons behind that destruction and decreasing in agriculture cover observed. The most mining extraction process and new mine caol pits are situated in agriculture land area.

A 3-year time scale reveals that mine activities leads to change in land use land cover catogories in the area. On the other hand it can be observed from the data that there is a shrunken in the area of all of the landforms from the year 1992 to 2019, except mine and grass cover area (Table 1).

Table 1. Areal distribution of LULC classes in the V.D. Yalevesky coal mine area (expressed in $\mathrm{km}^{2}$; valuse in parenthesis indicate percentages).

\begin{tabular}{|l|c|c|c|c|c|c|}
\hline Land use category & 1992 & $\%$ & 2006 & $\%$ & 2019 & $\%$ \\
\hline Forest & 241.01 & $(39.16)$ & 245.40 & $(39.87)$ & 215.66 & $(35.04)$ \\
\hline Water bodies & 2.12 & $(0.34)$ & 1.94 & $(0.32)$ & 1.18 & $(0.19)$ \\
\hline Road & 12.26 & $(1.99)$ & 4.67 & $(0.76)$ & 1.46 & $(0.24)$ \\
\hline Mining area & 10.68 & $(1.74)$ & 43.89 & $(7.13)$ & 111.40 & $(18.10)$ \\
\hline Agriculture & 206.83 & $(33.60)$ & 168.01 & $(27.30)$ & 108.35 & $(17.60)$ \\
\hline Grass & 142.60 & $(23.17)$ & 151.60 & $(24.63)$ & 177.46 & $(28.83)$ \\
\hline
\end{tabular}

\subsection{Rate of LULC change}

The statistics of change detection analysis for the study period 1992-2019 for each class are shown in Table 3. It is observed that the forest cover shows an increase, but at a slow rate, $4.38 \mathrm{~km}^{2}\left(0.31 \mathrm{~km}^{2} /\right.$ year $)$ during the years $1992-2016$, however decreasing to $-29.74 \mathrm{~km}^{2}(-$ $2.29 \mathrm{~km}^{2} /$ year) during the years $2006-2019$.

Results show that, the net rate change of forest is $-25.35 \mathrm{~km}^{2}\left(-0.94 \mathrm{~km}^{2} /\right.$ year $)$, during the study period.

The water bodies observed as the smallest rate in the area, and gradually decreased to $0.17 \mathrm{~km}^{2}\left(-0.01 \mathrm{~km}^{2} /\right.$ year $)$ during the years $1992-2006$, again and again $-0.77 \mathrm{~km}^{2}(-$ $0.06 \mathrm{~km}^{2} /$ year) during the years $2006-2019$. The shrunken in net rate change of water bodies is $-0.94 \mathrm{~km}^{2}\left(-0.03 \mathrm{~km}^{2} /\right.$ year $)$, during the study period.

The road class area decreased gradually to $-7.59 \mathrm{~km}^{2}\left(-0.54 \mathrm{~km}^{2} /\right.$ year $)$ during the years $1992-2006$, again and again to $-3.21 \mathrm{~km}^{2}\left(-0.25 \mathrm{~km}^{2} /\right.$ year $)$ during the years $2006-2019$. Decrecment during the period of the study area results is $-10.80 \mathrm{~km}^{2}(-0.4 \mathrm{~km} 2 /$ year $)$. However, change rate of mining and grass area is observed grown continuously during the study period with a net rate change $100.72 \mathrm{~km}^{2}$ of mine $\left(3.73 \mathrm{~km}^{2} /\right.$ year) and $34.86 \mathrm{~km}^{2}$ of $\left(1.29 \mathrm{~km}^{2} /\right.$ year $)$ of grassrespectively.

Mining and grass areas witnessed maximum increment in change rate at $33.21 \mathrm{~km}^{2}$ $\left(2.37 \mathrm{~km}^{2} /\right.$ year $)$ in mine coal area and $9 \mathrm{~km}^{2}\left(0.64 \mathrm{~km}^{2} /\right.$ year $)$ in grass cover area respectively 
during the period $1992-2006$, also $67.51 \mathrm{~km}^{2}\left(5.19 \mathrm{~km}^{2} /\right.$ year $)$ in mine coal area and $25.86 \mathrm{~km}^{2}\left(1.99 \mathrm{~km}^{2} /\right.$ year $)$ in grass cover respectively during the period 2006-2019.

Substantial decreace in agriculture cover area observed gradually. The net rate change of agricultural area between $1992-2006$ was $-38.82 \mathrm{~km}^{2}\left(-2.77 \mathrm{~km}^{2} /\right.$ year $)$, and $-59.66 \mathrm{~km}^{2}(-$ $4.59 \mathrm{~km}^{2} /$ year) between $2006-2019$. The most chnage has been occured in the last years. The results show the big conversion in agricultural land cover during the study period, which is $-98.48 \mathrm{~km}^{2}\left(-3.65 \mathrm{~km}^{2} /\right.$ year $)$

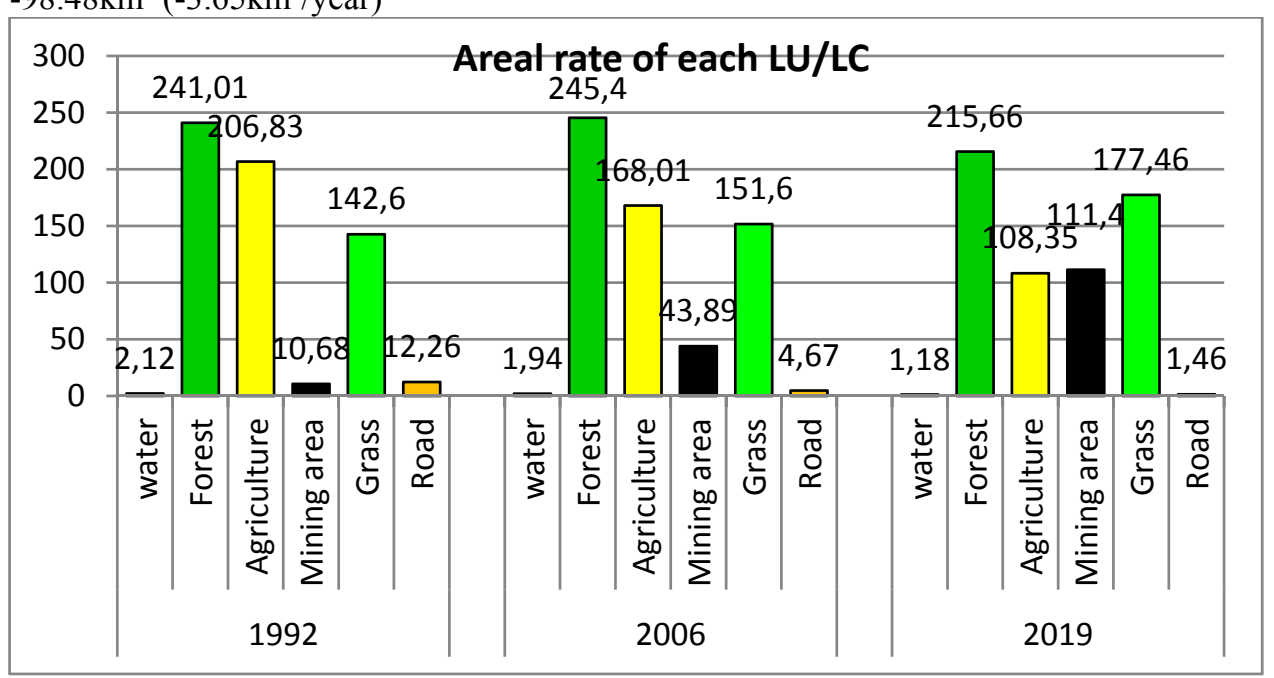

Fig. 3. Show the areal rate of each classes according to the years 1992, 2006 and 2019.

The study reveals that during the year 1992-2019 maximum positive change is observed in the mining area, whereas maximum negative change recorded in agriculture land cover (Table 2). Inadition maximum increase in the classes on the area observed in mining area and consequently the maximum decrease in agriculture cover are observed during 1992-2019. It is observed that except natural and other anthropogenic activities, the mining activities in the area is a significant driver to decreas in LULC catogories, and change their rates during the period from 1992 to 2019. Results of accuracy assessment of the classifed images showed that, the overall accuracy and kappa coefficient were found at $90.18 \%$ and 0.87 for 1992 classified image, 93.41\% and 0.91 for 2006 classified image, $88.69 \%$ and 0.85 for 2019 classified image respectively for LULC classified images.

Table 2. Rate of change and net change of LULC in the V.D. Yalevesky coal mine area (change expresed in $\mathrm{km}^{2} /$ year).

\begin{tabular}{|l|l|l|l|l|l|l|}
\hline $\begin{array}{l}\text { Land use } \\
\text { category }\end{array}$ & $\begin{array}{l}1992- \\
2006\end{array}$ & $\mathrm{~km}^{2} /$ Year & $\begin{array}{l}2006- \\
2019\end{array}$ & $\mathrm{~km}^{2} /$ Year & $\begin{array}{l}\text { Net change } \\
1992-2019\end{array}$ & $\mathrm{~km}^{2} /$ Year \\
\hline Forest & 4.38 & 0.31 & -29.74 & -2.29 & -25.35 & -0.94 \\
\hline Water bodies & -0.17 & -0.01 & -0.77 & -0.06 & -0.94 & -0.03 \\
\hline Road & -7.59 & -0.54 & -3.21 & -0.25 & -10.80 & -0.4 \\
\hline Mining area & 33.21 & 0.54 & 67.51 & 5.19 & 100.72 & 3.73 \\
\hline Agriculture & -38.82 & -2.77 & -59.66 & -4.59 & -98.48 & -3.65 \\
\hline Grass & 9.00 & 0.64 & 25.86 & 1.99 & 34.86 & 1.29 \\
\hline
\end{tabular}


Table 3. Change matrix of LULC change in V.D. Yalevesky coal mine area from 1992-2019 $\left(\mathrm{km}^{2}\right)$.

\begin{tabular}{|l|l|l|l|l|l|l|l|}
\hline $\begin{array}{l}\text { Land use } \\
\text { category }\end{array}$ & Forest & $\begin{array}{l}\text { Water } \\
\text { bodies }\end{array}$ & Road & $\begin{array}{l}\text { Mining } \\
\text { area }\end{array}$ & Agriculture & Grass & $\begin{array}{l}\text { Total } \\
1990\end{array}$ \\
\hline Forest & 187.78 & 0.03 & 0.57 & 0.28 & 15.15 & 11.85 & 215.66 \\
\hline Water bodies & 0.21 & 0.32 & 0.04 & 0.01 & 0.21 & 0.38 & 1.18 \\
\hline Road & 0.38 & 0.01 & 0.09 & 0.08 & 0.48 & 0.43 & 0.46 \\
\hline Mining area & 26.66 & 1.63 & 8.76 & 6.14 & 35.44 & 32.77 & 111.40 \\
\hline Agriculture & 8.50 & 0.07 & 1.97 & 2.39 & 80.89 & 14.52 & 108.35 \\
\hline Grass & 17.47 & 0.07 & 0.84 & 1.78 & 74.65 & 82.65 & 177.46 \\
\hline Total2019 & 241.01 & 2.12 & 12.26 & 10.68 & 206.83 & 142.6 & \\
\hline Class changes & 53.23 & 1.79 & 12.18 & 4.54 & 125.94 & 59.95 & \\
\hline Image difference & -25.35 & -0.94 & -10.80 & 100.7 & -98.48 & 34.86 & \\
\hline
\end{tabular}

\section{Conclusion}

The remote sensing imagery have been used to analyze LULC changes in the V. D. Yalevsky coal mine area. Six major LULC classes have been clearly identified from the mining area of V. D. Yalevsky basin. The study also provides the trend of major changes in the LULC classes of study area during the time period from 1992 to 2019. It is observed there is a direct impact of mining on majority LULC categories along with other factors. This study helps that in decision making for land reclamation and land management in the area. It will be a base data source to other invironmental issue such as change in climate and air polution. The study, employing Landsat-4 (TM) and Landsat-8 (OLI) has given satisfactorily results for classification of six major land cover classes of V. D. Yalevsky mine area. The dominant LULC class was mine area. The results clearly show that mining area increasing whereas agriculture, road, forest, and water are reducing. The use of this approach in the area has clearly demonstrated the potential of remote sensing imagery and its techniques in measuring the change pattern of LULC in the area characterized by the influx of mining. On the other hand the study would aid government and environmental protection agency (EPA) fashion out policy for potential environmental changes in the area.

\section{Acknowledgements}

The author would like to thank Professor Andrian Batugin and Mr. Manevich Alexandr Ilyich for his help in various ways.

\section{References}

1. Babkov-Esterkin at al, Mining and Environment. Textbook for engineers and masters Volume Part 3 (Moscow, 1999)

2. S. G. Gendler, S. V. Kovshov. Eurasian mining, 1, $45-49$ (2016) DOI 10.17580/em.2016.01.08

3. A. Batugin E3S Web of Conferences, 56, 02007 (2018). DOI. 10.1051/e3sconf/20185602007

4. M. Hendrychova, M. Kabrna, Applied Geography, 74, 151-159 (2016) DOI: 10.1016/j.apgeog.2016.07.009 
5. A. Singh, International Journal of Remote Sensing, 10(6), 989-1003 (1989) DOI: 10.1080/01431168908903939

6. A. Ruiz-Luna, C.A. Berlanga-Robles, Landscape Ecol, 18(2), 159-171 (2013) DOI: $10.1023 / \mathrm{A}: 1024461215456$

7. E.F. Lambin, H.J. Geist, E. Lepers, Annual Review of environment and recources, 28, 205-241 (2003) DOI: 10.1146/annurev.energy.28.050302.105459

8. A.I. Kopytov, Yu.A. Manakov, A.N. Kupriyanov. Coal mining and issues of ecosystem preservation in Kuzbass. Ugol, 3, 72-77 (2017) DOI: http://dx.doi.org/10.18796/0041-5790-2017-3-72-77

9. V. A. Malashkina, Mining Informational and Analytical Bulletin, 7, 69-75 (2018) DOI: $10.25018 / 0236-1493-2018-7-0-69-75$

10. S. V. Balovtsev, Mining Informational and Analytical Bulletin, 11, 218-226 (2018) DOI: 10.25018/0236-1493-2018-11-0-218-226

11. O.V. Skopintseva, S.D. Ganova, N.V. Demin, V.I. Papichev, Gornyy zhurnal, 11, 97-100 (2018) DOI: 10. 17580/gzh.2018.11.18.

12. E. Y. Kulikova, A. L. Ivannikov, IOP Conf. Series: Journal of Physics, Conf. Series 1425, 012062 (2020). doi:10.1088/1742-6596/1425/1/012062

13. S. V. Slastunov, K. S. Kolikov, G. P. Ermak \& E. P. Yutyaev, Gornyi Zhurnal, 4, 46-49 (2015). doi:10.17580/gzh.2015.04.08

14. A. Batugin, V. Odintsev, Yu Lijiang, K. Kolikov, Ev. Khotchenkov. Proceedings of the 18th International Multidisciplinary Scientific GeoConference (SGEM-2018), Albena (Bulgaria) 02-08 July 2018, 18(1.3), 319-326 (2018) doi.org/10.5593/sgem2018/1.3

15. G. Bocco, M. Mendoza, A. Velazquez, Science direct, Geomorphology, 39(3-4), 211-219 (2009) DOI: 10.1016/S0169-555X(01)00027-7

16. B.L. Turner, E.F. Lambin, A. Reenberg, Publmed.gov, 104(52), 1-7 (2007) DOI: 10.1073/pnas.0704119104

17. F. Yuan, K.E. Sawaya, B.C. Loeffelhoz, M.E. Bauer, Remote Sensing of environment, 98, 317-328 (2005) DOI: 10.1016/j.rse.2005.08.006

18. M. Story, R.G. Congalton, Photogrammetric engineering and remote sensing, 52(3), 397-399 (1986) DOI: 0099-1112/86/5203-397\$02.25/0

19. M. Shivangi, Sh. Priyanka, D. Priyanka, International journal of wireless and mobile communcation for industrial systems, $\mathbf{4 ( 1 )}$, $1-8$ (2017) DOI: 10.21742/ijwmcis.2017.4.1.01

20. E.A. El Gammal, S.M. Salem, A.E.A. El Gammal, Egypt Journal of Remote Sensing \& Space Science, 13(2), 89-99 (2010) DOI: 10.1016/j.ejrs.2010.08.001

21. Landsat science, URL:http://landsat.gsfc.nasa.gov

22. Earth explorer, 2020, URL:http://earthexplorer.usgs.gov/

23. C. Lea, A.C. Curtis, National park service vegetation inventory, Version 2.0.Natural resource report NPS/NRPC/NRR-2010/204.- (National park Service, Fort Collins, Colorado, USA, 2010)

24. D. Lu, Q. Weng, Photogrammetric engineering and remote sensing, 71(11), 12751284 (2005) DOI: 10.14358/PERS.71.11.1275

25. P.M. Harris, S.J. Ventura, Photogrammetric engineering and remote sensing, 61(8), 993-998 (1995) 